\title{
EFFECT OF SOCIAL MEDIA MARKETING AND HUMAN RELATIONS MANAGEMENT ON BRAND LOYALTY IN NIGERIAN TELECOMMUNICATION INDUSTRY
}

\author{
YUSUFF,MulkatAjibola ${ }^{1}$, ODUBANJO,Abimbola Omolade ${ }^{2}$ \\ Department of General Studies ${ }^{1}$, Department of Marketing ${ }^{2}$ \\ The Federal Polytechnic, Ilaro. \\ E-mails: mulikat.yusuff@federalpolyilaro.edu.ng ${ }^{1}$, odelolaa@yahoo.com ${ }^{2}$
}

DOI: 10.36108/ljerhrm/0202.02.0101

\begin{abstract}
The study investigated the effect of social media marketing and human relations on brand loyalty in Nigeria telecommunication industry. The broad objective of this study was to determine the significant effect of social media marketing and human relations on brand loyalty in Nigeria telecommunication industry. Survey research method was adopted for gathering data for this study. The target population was 814 staff of the federal polytechnic, Ilaro who were representative of customers of telecommunication industry and social media users who followed at least a telecommunication brand on social media platform. Regression method was used to analyze the data. The study revealed that social media marketing practices have significant effect on brand loyalty. This indicates that the types of adverts placed on social media platform, is capable of boosting brand loyalty. Also the study found that social media interaction through their customer service has significant effect on brand loyalty. The study recommended that the Nigerian telecommunication industry should continue to place relevant advert on their social media site so as to get their customers attracted towards their site, hence, leading to brand loyalty of their network.
\end{abstract}

Keyword: Brand Loyalty, Advertisement, Interaction, Entertainment, Social Media Marketing.

\section{Introduction}

Today, social media marketing is one of the fastest developing, growing and most potent branch of marketing because businesses operate in a highly competitive and dynamic environment. Therefore, one of the most vital competitive advantages for organizations is to have permanent and loyal customers for service organizations especially telecommunication industry (Ganjavi, Farahani, Hoseinabadi\&Rouzbehani, 2015). Social media marketing is different from traditional methods of marketing; therefore, it requires special attention, relationship building and strategy building to achieve brand image and loyalty. Social media marketing is related to relationship marketing, where the firms needs to shift from "trying to sell" to "making connections" with the consumers (Gordhamer, 2009). Companies also need to keep away from "big campaigns" and stick with "small acts" since some small campaigns can easily reach lots of people and accomplish the objectives in a very short period of time (Coon, 2010). Social media marketing is also more sincere in its communication with the consumers, trying to show what the brand is rather than trying to control its image. Finally, today's customers are more powerful and busy; therefore company should be reachable and available in every social media communication channel such as Facebook, Twitter, Blogs, Forums at any time (Gordhamer, 2009). 
The human relations movement emerged around 1930s in USA to cope with dehumanization of individuals in organizations; it emphasized on the study of the behaviour of workers in organizations, and examined the effects of social relations, motivation and employee satisfaction on productivity. According to Mayhew (2017), employee has been considered as the main assets of the company in terms of their skills and their performance that is valuable to the organization success. Tirintetaake (2017) opines that the organization successfulness depends on how well the employer applies different approaches to manage their employee. Managing employee is a great task to the employer, because he/she will try to guide the employee in day-to-day according to the organization's objectives. Therefore, a wellmanaged employee would have a positive interaction with the organization customers because there is a general saying that it is a happy staff that leads to happy customers and at the end to happy shareholders.

Building and maintaining brand loyalty are one of the central themes of research for marketers for a very long time (Oliver, 1997; Chaudhuri \& Halbrook, 2001; Bennett \& Rundle-Thiele, 2002). Brand loyalty can be conceptualized as the final dimension of consumer brand resonance symbolizing with customer's ultimate relationship and level of identification with a brand (Keller, 2008). As brands gain exclusive, positive, and prominent meaning in the minds of a large number of consumers, they become irresistible and irreplaceable, and win the loyalty of the consumers. Brand loyalty, in return, brings sales revenues, market share, profitability to the firms, and help them grow or at least maintain themselves in the marketplace (Keller, 2008; Aaker, 1991, Kapferer, 1997). Marketers have utilized various means to maintain the brand loyalty of their customers, including brand elements, classical marketing mix variables, and new methods of marketing such as events, sponsorships, one-to-one marketing activities, Internet marketing, social media marketing and human relations management (Keller, 2008; Kotler \& Keller, 2007).

Customers who are treated in a positive way by a firm employees as a result of how the firm also treated him/her would definitely exposed to plenty of brand messages on social media platforms filter out the entertainment that is not relevant to them (Brito, 2011). Therefore, providing relevant and updated entertainments is one of the most crucial strategies to manage a brand on social media successfully. Popularity of the social media platform and the entertainments among friends is another important reason for the customers to be engaged with brands on social media. Since there are plenty of social media platforms and it is impossible to involve in all of them, marketers should analyze their target audience and decide to participate in the most effective platforms to communicate with them. In addition, providing mobile applications allow customers to engage with the brand every day and create brand loyalty (Kim \& Adler, 2011).

There has been a paradigm shift and the traditional marketing(that is television, radio, newspapers and magazines) do not suffice on their own anymore, given the abundance of loop holes inherent in advertising via these mediums especially in the aspect of feedback, online/social media advertising has gained grounds. Recent studies indicate that traditional mass media audiences are increasingly and to a great extent turning toward the new media for information and gratification of certain communication needs, (Rudloff\& Fray; 2010, O'Toole cited in Otuogoet al, 2015). Olotewo (2016) corroborates thus; traditional marketing communicates with customers through dedicated media channels like television, radio, newspapers, magazines; but the failure of traditional marketing channels to yield significant 
returns on investment is attributed to many reasons including lack of interactive engagement between the customers and the brand; social media appeared as the solution to the let-down of traditional marketing. Social media advertising is no longer considered passé given this era of collaborative, interactive, customize and collective information sharing where one-directional communication is now ineffective and the audience is no more just a passive consumer but an active participator in the communication process. Online businesses world over have taken the initiative and are taking advantage of numerous benefits of social media advertising and Nigerian businesses are not left out.

In Nigeria and parts of Africa, the diffusion of new digital technologies and their use are increasing by the day (Otuogo et al, 2015). Olotewo (2016) asserts that in emerging economies like Nigeria, social media marketing is gaining traction...however another force which undercuts emerging economies the benefit of social media marketing is the slow adoption of social media marketing in such countries. It is based on this premise that an analysis of the effect of social media marketing and human relations management on brand loyalty in Nigeria is necessitated.

Therefore, the broad objective of this study was to determine the significant effect of social media marketing and human relations management on brand loyalty in Nigerian mobile telecommunication industry.

Derived from the above broad objective are the following specific objectives:

1. To determine the significant effect of social media marketing on brand loyalty;

2. To determine the significant effect of human relations management on brand loyalty

This paper is divided into five sections. The first is the introduction; the second examines the literatures such as conceptual and empirical frameworks of the paper; the third section elucidates the research methods used; the fourth section presents the results and discussion while the fifth section is the conclusion and recommendations.

\section{Literature Review}

\section{Concept of Social Media Marketing}

Igyuve and Agbele (2017) described social media as specialized websites (such as Facebook, Twitter, Mobofree, Eskimi, MySpace, Badoo etc) and applications (such as Whatsapp, Instagram, Blackberry Messenger BBM, Skype etc) used for communicating and establishing forms of relationship between/amongst people of similar interest. According to Pinto and Yagnik, (2017) social media marketing consists of tools, platforms and applications that enable customers connect and communicate with each other. Yazdanparast, Joseph and Muniz, (2016) define Social media marketing as the process that empowers promotion of websites, products, and services via online social channels. It involve with marketing related activities such as blogging, sharing photos and posts online. Today social media becomes fast advancing and most solid medium to connect and stay informed about products and services (Rishi \& Sharma, 2017).

Social Media marketing is a part of internet marketing. It is a platform that can be used by anyone who has an internet connection. Social media marketing can be easily characterized as a 
term used to portray the act of increasing website traffic or brand awareness, using social media networking sites. Social Media marketing mainly focuses on designing an entertainment that is very unique and helps in attracting the attention of the users. It should also persuade the viewers to share it with others. This type of marketing is driven by eWoM - electronic word of mouth, which means it results in earned media instead of paid media (Atshaya\&Rungta, 2016). Lamminen (2018) as cited in identified the most popular social network sites worldwide as of January 2018, ranked by number of active users (in millions) are as it can be seen from Table 1:

Table 1- Number of active social media users worldwide as at January 2018

\begin{tabular}{|l|l|}
\hline Name of social media & Number of active users in millions \\
\hline Facebook & 2,167 \\
\hline YouTube & 1,500 \\
\hline WhatsApp & 1,300 \\
\hline Facebook Messenger & 1,300 \\
\hline WeChat & 980 \\
\hline QQ & 843 \\
\hline Instagram & 800 \\
\hline Tumblr & 794 \\
\hline QZone & 368 \\
\hline SkinaWeibo & 300 \\
\hline Twitter & 300 \\
\hline
\end{tabular}

Source:Lamminen (2018)

Social media is comprised of those interactive platforms on the internet, which may be web or mobile-based, that involve user-generated entertainments and their main purpose is social interaction. They often gather people who share common interests. It is essential that these pages are interactive; the interaction is bi- or multidirectional. Characteristically the communication on these websites happens as individual people. (Cite 2012; Nations 2012; Turban,King, Lee, Liang, \& Turban; 2015;\&Durango).It is only possible for social media to have a functional role in the 
marketing actions of businesses with framing, defining and applying marketing activities in an effective way on social media. One of the leading classifications of social media marketing activities has been carried out by (Kim \&Ko, 2012). Kim and Ko (2012) have categorized social media marketing activities for luxurious brands as entertainment, interaction, trendiness, customization, and word of mouth communication. Koivulehto (2017) has added the purchase intention to these components. Seo and Park (2018) have defined social media marketing activities in airline industry as entertainment, interaction, trendiness, customization and perceived risk. Sano (2014) has identified the components of social media marketing in insurance services as interaction, trendiness, customization, and perceived risk. Jo (2013) has referred to marketing activities as events, information and advertisement on social networks. Yadav and Rahman (2017) have categorized social media marketing activities as interaction, trendiness, information, customization, and word of mouth communication. In this research, social media marketing activities have been considered as entertainment, interaction, trendiness, advertisement and customization.

\section{Components of Social Media Marketing}

\section{Entertainment}

Entertainment is a crucial component that encourages participant behavior and the continuity of follow-up, which creates positive emotions/feelings about the brand in the minds of followers' on social media (Kang, 2005). Even if the reasons for using social media differ, individuals emphasize that the entertainments which arouses the attention of them who finds the entertainments amusing and pleasing (Manthiou, Chiang \& Tang, 2013). In this respect, with providing entertaining shares, businesses should encourage liking and sharing of large number of individuals and be able to turn it into advantage (Schivinski\&Dabrowski, 2015). Previously, blogs were also only about written information, but today's practices showed that blogs are also affected by visualization. More and more pictures appear in the posts every day (DeMers, 2013). The information which contains images is always more memorable, associative and interesting. For example, MTN customers can watch their "who wants to be a millionaire" online, the popular MTN project fame can be watched anywhere in the word online and even the voting is done online too. This is a great deal of entertainment for MTN. MTN allowed customers to attach pictures to their comments and reviews that attract more audience to interact with the company and other users. Video images of the brand could also carry out some structural functions, form and unite the text.

In today's entertainments should be recognizable, but not too pushy or aggressive, because people are overloaded by different ads which are reaching them every minute. That is why simplicity and clearness are highly appreciated by the modern consumer. The content of the entertainments should be interesting and guiding for the customer to consider products of the company (DeMers, 2013). Customers get entertained through the "My Mtn app" and "My Music app" and this is a way to keep customers' loyalty with their brand. 


\section{Interaction}

In today's information age, social media has become an integral part of daily life as a communication channel in which consumers reflect their consumption habits, preferences, opinions, likes and experiences in their own eyes and interact with other users. This widespread communication area where consumers interact with each other and with other users, offer significant opportunities for product and brand communication actions, such as cost, time and ease of reaching large consumer masses. For this purpose, many businesses create their own brand profiles on social media communication channels and develop activities that will engage consumers with content sharing such as online product information, discounts, advertisements and promotions.

Social media is becoming the newest and up-to-date source of information for customers (Hamid, Bukhari, Ravana, Norman \&Ijab, 2016) because information is simultaneously shared in real time on the social media. Unlike traditional mass communication channels, social media facilitate the interaction, entertainments sharing and collaboration of businesses with their customers (Wang, 2012). By utilizing social media as interactive communication between business and customer, it is possible to obtain requests and needs of customers, their opinions and suggestions on the product and brand in real time (Vukasovic, 2013). Trendiness as another component of social media marketing activities means introducing the latest/current information on products for customers (Godey et al., 2016).

Social media is used to gain the attention and involvement of consumers by many brands around the world (Graves, 2016). According to Celaya (2008), when companies include social media programs in their marketing, the main return they are looking for is to improve the interaction with their clients and to increase their sales. The fact that these interactions are formed without intervention of the business has increased the level of trust of the consumers. The ultimate goal of social media marketing activities is to acquire new customers, increase sales, strengthen word of mouth communication and create customer loyalty (Tsimonis\&Dimitriadis, 2014). Contrary to the traditional branding paradigm (consecutive investments and directing the image through controlled communication), social media communications actualize on a platform where the limits are uncertain, and the businesses' chances of intervention are very limited (Kohli, Suri, \& Kapoor, 2015).

The sharing about a product or a brand have risk but content that created by the customers and peer to peer communication influences other consumers' purchasing decisions (Sashi, 2012). Moreover, firms actively utilize these kinds of content and generated information created by customers in social media marketing actions (So,Wu, Xiong, \& King, 2017). Hajli (2013) has found that social media influences customers' trust sentiment and purchasing intent beyond easing interactions among consumers. In this sense, social media is an efficient way of interacting with current and potential customers for businesses and developing a positive brand image (Halligan \& Shah, 2009; Fortezza \&Pencarelli, 2015).

\section{Advertisement}

The advertising as a component refers to advertising and promotional campaigns that businesses have made through social media to increase sales and develop customer portfolio. Findings of Duffett (2017); Alalwan, Rana, Dwivedi, and Algharabat (2017) on the effects of social media 
advertisings on perceptions and awareness of the customers have shown that advertising is one of the significant parts of social media marketing activities (Mangold \& Faulds, 2009).

Cyber space is used widely for interaction, education, organization, sharing movements' cultural products, communication, advertisements, correlation creation, etc. by social movements. Some people have doubted full-scale and determining role of cyberspace in social movements, which refers to inequality in internet accessibility and lack of pervasiveness of movements' extent. Even if there is accessibility, some people look at the principle of its useful and democratic using quality in social movements doubtfully (Khaniki\&Babaie, 2011). There is a very serious advertising campaign to keep customers. Valid companies interact with their customers by applying online customer's loyalty programs through providing special advertisement (Mangold \&Foulds, 2009). It is also possible to interact with cyber space via new mechanisms such as social networks, weblogs, e-mails, websites, chat rooms, video conferences; instant massage recording systems, post lists, discussion forums and podcast, each of them provides a certain level of interaction with respect to its characteristic. Communication mechanism is selected according to interaction target and software environment needs and necessities, so that outcomes and consequences of interaction through them will differ (Khaniki\&Babaie, 2011).

\section{Customization}

The customization as a component is the act of creating a customer satisfaction based on the contact of the business with individual users (Ding \&Keh, 2016; Seo\& Park, 2018). Businesses on the social media can transfer the uniqueness of the product and brand to the customers by means of peer to peer communication. And they can deal with their individual problems and can be influential on product and brand preferences by making touches that will make them feel important. The direct marketing mean strongly reliable on the digitalized ways of communication is called email marketing. It is as simple as massaging potential or already existing customers through email. Different targets can be reached through email. The significant advantage of this tool of online marketing communication is that relationships with customers can be managed and regulated outstandingly well, that is why it is used in CRM.

On another hand, email marketing is very direct and can be narrowed down to the desired audience very accurately. Obviously, it is not the only one advantage of email marketing. It also can be a cost saver, which can be well customized, measured and modified (Stokes, 2011). It is worth to mention that email marketing has some options of the messages. A single message can represent a direct marketing or carry company related material. The first is known as a promotional message and the other one as a newsletter (Stokes, 2011). The message should never be fully independent, but necessarily connected to the online marketing purposes of the company. The direct information leading to concrete actions such as order or information request is more likely to appear in the promotional message, while newsletters are genuinely sanctifying company related changes and have long-term nature (Stokes, 2011; \& Fore, 2016).

Apart from already mentioned newsletters and promotional emails, there are catalogues, invitations, alerts and communicational messages. Despite the choice, which email marketing provides to businesses, it cannot be used thoughtlessly without any distinguished plan. Targeting and building the email marketing strategy should be planned well in advance with small detail consideration and knowledge about audience interests. The data about market should be 
supportive of the design process and eliminate un-necessary risks from the shoulders of marketers. The biggest difference is made when the marketing campaign starts and emails start to reach hands of its receivers (Hollier, 2016).

\section{Human Relations Management}

Today, it is integral to every business, and understanding the involved skills and theories are key to employee's success. Mayo (1949) stated that working places should be like as a social environment and good relationship should be maintained between all the workers. People are motivated by much more than self-interest. A human relation is defined as the systematic study and application of knowledge about how individuals and groups act within the organizations where they work. Human relations are the study of the ways in which people relate to each other in group situations, especially work, and how communication skills and sensitivity to other people's feelings can be improved.

According to Davis, human relations deal with motivating people in organizations to develop teamwork which effectively fulfill their objectives and achieves organizational objectives. In the words of Scott, 'human relations is a process of an effective motivation of individuals in a given situation in order to achieve a balance of objectives which will yield greater human satisfaction and help accomplish company goals'. Human relations can also be seen as the cordial atmosphere in an organization in which people practice the art of living in such a way that they communicate, act, interact and transact in a cordial manner, recognizing each other's needs, views, values and temperaments so that every interaction and transaction taking place in an organization would have concern for each other's interests and feelings. This would lead to better motivation and morale of people at all levels in the organization.

\section{Brand Loyalty}

The concept of brand loyalty has been recognised as an important construct in the marketing literature for at least four decades (Howard \&Sheth, 1969). Brand loyalty is an aspect of brand equity, there are five dimensions of brand equity which brand loyalty is one of them and these dimensions include; brand loyalty, brand awareness, brand association, customers' perception of its quality and other proprietary brand assets that is intangible assets such as patents, trademarks etc. (Craven, 1997). Brand loyalty is a consumer's preference to buy a particular brand in a product category. It occurs when consumers perceive that the brand offers the right product features, images or level of quality at the right price. This perception may translate into repeat purchase resulting in loyalty. Brand Loyalty is therefore related to a customer's preference and attachment to a brand. It may occur due to a long history of using a product and trust that has developed as a consequence of the long usage.

Brand loyalty has also be seen as a sort of commitment towards the brand that induces a re-buy behavior into the customer in spite of the potential marketing attempts by competitors to break up the coalition between the brand and the consumer (Oliver, 1999; Awan, \& Rehman, 2014). Brand loyalty is considered to provide greater leverage to trade, condensed marketing costs (Aaker, 1991; Awan, \& Rehman, 2014) and building an augmented market share (Jarvis \& Mayo, 1986; Awan, \& Rehman, 2014). Although, the terms 'satisfaction' and 'loyalty' are sometimes used interchangeably, we have seen that they do not necessarily correspond. 
'Customer satisfaction' refers to the degree a customer is happy about the quality of products and services. As a customer's satisfaction with products and/or services increases, so should their behavioural and emotional loyalty.

\section{Social Media Marketing and Brand Loyalty}

Social media marketing is different from traditional methods of marketing; therefore, it requires special attention and strategy building to achieve brand image and loyalty. Social media marketing is related to relationship marketing where the firms need to shift from "trying to sell" to" making connections" with the consumers (Gordhamer, 2009). Companies also need to keep away from "big campaigns" and stick with "small acts" since some small campaigns can easily reach lots of people and accomplish the objectives in a very short period of time (Coon, 2010). Social media marketing is also more sincere in its communication with the consumers, trying to show what the brand is rather than trying to control its image.

Since, today's customers are more powerful and busy; therefore, companies should be reachable and available in every social media communication channel such as Facebook, Twitter, Blogs, YouTube,WhatsApp, Facebook Messenger, WeChat, QQ, Instagram, Tumblr, Skype and Forums at any time (Gordhamer, 2009). Social media has been identified as an influence on brand image rather than the traditional media which focus on brand awareness. Further, as an element in the communication mix, social media has a significant impact on brand loyalty (Godey et al., 2016), the relationship between Social Media Marketing (SMM) and Brand Loyalty (BL) has been tested (Jayasuriyal \& Azam, 2017; Rishi \& Sharma, 2017). Social media becomes fast advancing and most solid medium to connect and stay informed about products and services

\section{Human Relations Management and Brand Loyalty}

Mayo introduced human relations theory' to help the employer to increase the productivity of the workplace. Whatever activities employees perform in a service organization connect its organization to the customers (Grönroos, 1990). Such activities helps in fulfilling the promises made to the customers and thereby maintain customer loyalty (Berry, 1995). These employees' actions are of high importance in developing successful employee-customer relationship (Gwinner, Gremler, \& Bitner, 1998). Thus, employees are responsible for delivering the quality services to meet the customers' expectations (Zeithaml, Berry \& Parasuraman, 1996). The attitude of employees, their skills, and the other available support in delivering the service, are all the determinants of customer loyalty (Bitner, 1995; Reichheld, 1993).

\section{Operationalization of Variables}

$$
\begin{aligned}
& Y=f(X) \\
& X=X_{1}, X_{2} ; \\
& Y=\alpha+\beta_{1} X_{1}+\beta_{2} X_{2}+e
\end{aligned}
$$

Where: 
$\mathrm{Y}=$ Brand Loyalty (BL)

$\alpha=$ Constant

$\mathrm{X}_{1}=$ Social Media Marketing $(\mathrm{SMM})$

$\mathrm{X}_{2}=$ Human Relations Management $(\mathrm{HRM})$

$\beta_{\mathrm{i}}=$ Beta coefficients of the independent variables $\mathrm{Xi}$

$\mathrm{e}=$ Error term, which represent other not captured variables influencing Brand Loyalty outside the four captured by this work.

\section{Empirical Framework}

Erdogmus and Ricek (2012) research on the impact of social media marketing on brand loyalty and the study revealed that brand loyalty of the customers is positively affected when the brand (1) offers advantageous campaigns, (2) offers relevant content, (3) offers popular contents, (4) appears on various platforms and offers applications on social media.

In the work of Mehrabi, Islami and Aghajani (2014) this study focuses on the effect of social media marketing on customers' brand loyalty in Iran. The results of Pearson correlation test and regression test indicated a positive significant relationship between social media marketing and customers' brand loyalty. Furthermore, it was confirmed that there was a positive significant relationship between the dimensions of social media marketing and brand loyalty.

Bilgin (2018), studied the the effect of social media marketing activities on brand awareness, brand image and brand loyalty and it was reported that social media marketing activities have been found as effective factors on brand image and brand loyalty, besides it has been determined that the most obvious effect seen on brand awareness. In addition, it has been found out that brand awareness and brand image have a significant effect on brand loyalty.

Murtiningsih and Murad (2016) researched on the effect of social media marketing to brand loyalty a case of university of budiluhur Jakarta. The results of this study indicate that offer advantageous campaigns, offer relevant contents, offer popular content, appears on various platforms, offer applications on social media has a significant influence on brand loyalty.

Nwokah and Aeenee (2017) carried out a study on social media marketing and business success of automobile dealers in Rivers State, and it was reported that there is a significant relationship between social media (i.e. Facebook, Twitter and YouTube) that significantly influenced sales growth, market share and profitability.

\section{Methodology}

This study adopted descriptive survey research design. Descriptive research involves gathering data that describe events and then organizes, tabulates, depicts, and describes the data collection (Glass \& Hopkins, 1984). The target population was 814 staff of the federal polytechnic, Ilaro who were representative of customers of telecommunication industry, who was also social media users and followed at least a telecommunication brand on social media platform (FPI Registrar Office, 2019). The choice of telecommunication industry was necessitated by their increasing use 
of social media marketing and human relations management in promoting their various product offers to their customers in order to build brand loyalty among their customers.

Thus, the design of the study was a survey. A self-constructed questionnaire was developed base on likert scale by the researchers and self-administered to respondents. In order to encourage participation, these respondents were subsequently followed with a phone call to ensure that they responded to the questionnaire items. A total of 200 copies of the questionnaire were distributed among the staff of the institution, 150 copies were retrieved out of which 145 was fit for analysis, thus giving a retrieval rate of 80 percent. The respondents were selected randomly. This two hundred (200) respondents were selected from the five communication companies; MTN, Airtel, 9mobile, GLO, and VODACOM (i.e. forty (40) respondents from each company). The instrument was also tested for reliability using Cronbach's reliability and the coefficients were as follows:

\section{Table 1: Reliability of scale}

$\begin{array}{lll}\text { S/N } & \text { Variables } & \text { Cronbach's Alpha } \\ 1 & \text { Social media marketing } & 0.732 \\ 2 & \text { HRM } & 0.773 \\ 3 & \text { Brand loyalty } & 0.781\end{array}$

Source: Researcher's Computation, 2019

From the table above (table 1), it is shown that from the reliability results, this instrument is reliable since the reliability coefficients range from 0.732 to 0.781 and this could be used for the study. Data were analyzed using descriptive and inferential statistics.

\section{Results and Discussion}

\section{Hypotheses Testing}

$\mathrm{H}_{01}$ : There is no significant effect of social media marketing on brand loyalty

$\mathrm{H}_{02}$ : There is no significant effect of human relations management on brand loyalty

Table 2- Summary of the correlation Matrix

\section{Variable}

Brand Loyalty vs Social Media Marketing

Brand Loyalty vs Human Relations Management

Source: Researcher's Computation, 2019.

\begin{tabular}{lll}
$\begin{array}{l}\text { Correlation } \\
\text { Coefficient }\end{array}$ & Sig. value & $\begin{array}{l}\text { Number of } \\
\text { Observation }\end{array}$ \\
\hline 0.498 & $\mathbf{0 . 0 0 0}$ & 145 \\
0.427 & $\mathbf{0 . 0 0 0}$ & 145 \\
\hline
\end{tabular}

$\begin{array}{lll}\begin{array}{l}\text { Correlation } \\ \text { Coefficient }\end{array} & \text { Sig. value } & \begin{array}{l}\text { Number of } \\ \text { Observation }\end{array}\end{array}$

$\begin{array}{lll}0.498 & \mathbf{0 . 0 0 0} & 145\end{array}$

$\mathbf{0 . 0 0 0} \quad 145$ 
In other to establish the degree of the relationship between the variables under consideration, correlation analysis was carried out and the result is as indicated in table 2 . The result shows weak significant positive relationship between brand loyalty and social media marketing with correlation coefficient of 0.498. Similar result was obtained for brand loyalty and human relations Management with correlation coefficient of 0.427 .

Table 3- Summary of the Regression Model

$\begin{array}{lllll}\text { Variable } & \text { Regression coefficient } & \text { Standard Error } & \text { T } & \text { Sig. } \\ \text { SMM } & 0.315 & 0.141 & 2.236 & \mathbf{0 . 0 2 7} \\ \text { HRM } & 0.277 & 0.128 & 2.168 & \mathbf{0 . 0 3 2} \\ \text { Constant } & 9.184 & 1.636 & 5.616 & \mathbf{0 . 0 0 0}\end{array}$

Source: Researcher's Computation, 2019.

$\mathrm{R}=0.539, \mathrm{R}-$ Square $=0.291$, Adj. R-Square $=0.268$, Std. Error of the estimate $=3.100, \mathrm{~F}=$ 13.021, Sig. $=0.000$

The model can be specified as:

$\mathrm{BL}=9.184+0.315 * \mathrm{SMM}+0.277 * \mathrm{HRM}$

Where,

SMM stands for Social Media Marketing

HRM stands for Human Relations Management

Table 3 shows the summary of the regression model for the study. The result shows the regression coefficient for social media marketing and human relations management to be 0.315 and 0.277 respectively. The respective t-values are 2.236 and 2.168 with their p-values of 0.027 and 0.032 .

This result suggests that a unit increase in social media marketing keeping human relations constant will cause $31.5 \%$ increase in brand loyalty while a unit increase in human relations management keeping social media marketing constant will cause $27.7 \%$ increase in brand loyalty. However, in the absence of the two variables, brand loyalty stands at $18.4 \%$. That is for companies to achieve high level of customer brand loyalty, it advisable for them to increase level of their human relations as well practice social media marketing.

In addition, about $29.1 \%$ variations in brand loyalty can be attributed to the joint effects of social media marketing and human relations management. The F-value is 13.021 with significant value 
of 0.000 , showing that the model is adequate and sufficient in relating the relationship between the dependent and the independent variables.

\section{Conclusion and Recommendations}

The two components examined; social media marketing and human relations management are highly significant. Moreover, social media marketing shows more contributions to brand loyalty compared to other variable (i.e. human relations management). On this basis we concluded that social media marketing has significant effect on brand loyalty.

Based on the findings of this study, the followings are recommended for the improvement of social media marketing and human relations management in achieving brand loyalty in Nigerian telecommunication industry; Nigerian telecommunication industry should improve on posting relevant information on their social media site so as to get customers attracted towards their site.

Nigerian telecommunication industry should improve on event marketing activities (such as, sport, musical shows, talent hunts, and the likes) in order to achieve the entertainment component of social media marketing which will facilitate brand loyalty.Nigerian telecommunication industry should rely on visual and verbal marketing initiatives to attract and to engage online surfers.

\section{References}

Aaker, D. A. (1991).Managing Brand Equity. New York: The Free Press.

Alalwan, A. A., Rana, N. P., Dwivedi, Y. K. \&Algharabat, R. (2017). Social media in marketing: A review and analysis of the existing literature. Telematics and Informatics, 34 (7), 1177 1190.

Awan, A. G. \& Rehman, A. (2014). Impact of customer satisfaction on brand loyaltyanempirical analysis of home appliances in Pakistan, British Journal of Marketing Studies, 2 (8), 18 - 32.

Bennett, R. and S. Rundle-Thiele. (2002) A Comparison of Attitudinal Loyalty Measurement Approaches. Journal of Brand Management, 9(3) 193-209.

Berry, L. (1995) Relationship Marketing of Services. Growing Interest, Emerging Perspectives. Journal of the Academy of Marketing Science, 23, 236-245. http://dx.doi.org/10.1177/009207039502300402.

Bitner, M. J. (1995). Building Service Relationships: It's All about Promises. Journal of the Academy of Marketing Science, 23, 256-251. http://dx.doi.org/10.1177/009207039502300403.

Brito, M (2011). 3 Reasons Why Relevant Entertainments Matters, retrieved from http://www.socialmediaexplorer.com/social-mediamarketing/3-reasons-why-relevantentertainments-matters/ (accessed on 20 March 2012). 
Chaudhuri, A.\& Holbrook, M. B. (2001).The Chain of Effects from Brand Trust and Brand Affect to Brand Performance: The Role of Brand Loyalty. Journal of Marketing, 65 (April), 81-93.

Cite, (2012). [Web page] Different types of social media. [Ref. 28 Jan. 2016]. Available at: https://www.cite.co.uk/the-different-types-of-social-media/

Coon, M. (2010). Social Media Marketing: Successful Case Studies of Businesses Using Facebook and YouTube With M. A. Project, June 4, 2010, http://comm.stanford.edu/coterm/projects/2010/maddy\%20coon.pdf (accessed on 02 March 2012)

Duffett, R. G. (2017). Influence of social media marketing communications on young consumers' attitudes. Journal of Young Consumers, 18 (1), 19-39.

Durango, A. (2015). Mercadotecniaenlos MediosSociales.IT Campus Academy.

Erdogmus, \&Cicek (2012). The impact of social media marketing on brand loyalty, 8th International Strategic Management Conference

Erdogmus, I. E. \&Cicek, M. (2012). The Impact of Social Media Marketing on Brand Loyalty, Procedia.Journal Social and Behavioral Sciences, 58.

Eurostat, (2015). [Web page] Information society statistics - households and individ-uals Statistics Explained. [Ref. 22 Jan. 2019]. Available at:http://ec.europa.eu/eurostat/statistics-explained/index.php/Information_society_statistics__households_and_individuals

Freidman, A. (2011). Freshness Update + Social Media = Happy Users, retrieved from http://searchengineland.com/freshnessupdate-social-media-happy-users-102880 (accessed on 25 March 2019).

Ganjavi, F. S., Farahani, F. S., Hoseinabadi, A. R. \&Rouzbehani, A. (2015). Studying the Effect of Internal Marketing on Customer Loyalty: Case Study of A Private Bank in Iran. International Journal of Economics, Commerce and Management, 3 (7), 295 - 307.

Godey, B., Manthiou, A., Pederzoli, D., Rokka, J., Aiello, G., Donvito, R., \& Singh, R. (2016), Social media marketing efforts of luxury brands: Influence on brand equity and consumer behavior. Journal of Business Research, 69 (12), 5833-5841.

Grahl, T. (2016).The 6 Types of Social Media.[Web page]. Timgrahl.com. [Ref. 27 Jan. 2019]. Available at: http://timgrahl.com/the-6-types-of-social-media/

Graves, J. (2016). What Can Social Media Intelligence Do for Your Brand? [Web page] American Marketing Association. [Ref. 28 Jan. 2016]. Available at: https://www.ama.org/resources/Best-Practices/Pages/What-Can-Social-MediaIntelligence-Do-for-Your-Brand.aspx 
Grönroos, C. (1990). A Relationships Approach to Marketing: The Need for a New Paradigm. Working Paper 190, Swedish School of Economics, Helsinki.

Gwinner, K. P., Gremler, D. \& Bitner, M. J. (1998). Relational Benefits in Services Industries: The Consumer's Perspective. Journal of the Academy of Marketing Science, 26, 101-114. http://dx.doi.org/10.1177/0092070398262002

Hajli, M. N. (2013). A study of the impact of social media on consumers.InternationalJournal of Market Research, 56 (3), 387-404.

Hamid, S., Bukhari, S., Ravana, S. D., Norman, A. A. \&Ijab, M. T. (2016). Role of social media in information-seeking behaviour of international students: A systematic literature review. Aslib Journal of Information Management, 65 (8), 643-666.

Jayasuriya1, N. A. \& Azam, S. M. F. (2017). The Impact of Social Media Marketing on Brand Equity: A Study of Fashion-Wear Retail in Sri Lanka, International Review of Management and Marketing, 7 (5), 178 - 183.

Kang, M. J. (2005). A Study on the Effect of Features of Brand Community Using One-person Media on Consumers. Seoul: Seoul National University.

Kapferer, J. N. (1997). Strategic Brand Management: Creating and Sustaining Brand Equity Long Term. UK: Kogan Page

Keller, K. L. (2008). Strategic Brand Management: Building, Measuring and Managing Brand Equity (3rd Edition). New Jersey: Pearson Prentice Hall.

Kim, A. J. \& Ko, E. (2012). Do social media marketing activities enhance customer equity? An empirical study of luxury fashion brand. Journal of Business Research, 65 (10), 14801486.

Koivulehto, E. I. (2017). Do social media marketing activities enhance customer equity? A case study of fast-fashion brand Zara. Helsinki: Aalto University.

Kotler, P., \& Keller, K. L. (2007). A Framework for Marketing Management (3rd ed.). Upper Saddle River, NJ: Pearson/PrenticeHall.

Lamminen, A. (2018) as cited in Aliu, A. A. \&Agbetokun, F. A. (2018). Internet Marketing Practices and Customer Loyalty: Empirical Evidence from Ogun State, Nigeria, European Journal of Accounting, Finance and Business, 8 (18), 22-39.

Mangold, W. G. \& Faulds, D. J. (2009). Social media: The new hybrid element of the promotion mix. Business Horizons, 54 (2), 357-365.

Manthiou, A., Chiang, L. \& Tang, L. R. (2013). Identifying and Responding to Customer Needs on Facebook Fan Pages. International Journal of Technology and Human Interaction, 9 (3), 36-52. 
Mehrabi, A., Islami, H. \&Aghajani (2014). The Effect of Social Media Marketing on Customers' Brand Loyalty. International Journal of Academic Research in Business and Social Sciences, 4 (8), $480-495$.

Montero Torres, R. 2015. Las RedesSocialesen la Empresa.IT Campus Acad-emy.

Nations, D. (2012). [Web page] What is social media? [Ref. 03 October 2018]. Avail-able at: http://webtrends.about.com/od/web20/a/social-media.htm

Oliver, R. L. (1999). Whence Consumer Loyalty? Journal of Marketing, 63, 33-44.

Olotewo, J. (2016). Social media marketing in emerging markets, International Journal of Marketing Research 2 (2), 10--19.

Ova, M., Gonzalez-Roma, V. \& Bakker, A.B. (2002). The measurement of engagement and burnout: a two sample confirmatory factor analytic approach. Journal of Happiness, 2(5), $17-27$

Reichheld, F. F. (1993). Loyalty-Based Management. Harvard Business Review, 2, 64-73.

Rishi, O. P., \&Sharma, A. (2017), Maximizing Business Performance and Efficiency through Intelligent Systems. DOI: 10.4018/978-1-5225-2234-8.

Sano, K. (2014). Do Social Media Marketing Activities Enhance Customer Satisfaction, Promote Positive WOM and Affect Behavior Intention? Doshisha Commerce Journal, 3-4 (66), 491-515.

Schivinski, B. \& Dabrowski, D. (2015).The impact of brand communication on brand equity through. Journal of Research in Interactive Marketing, 9 (1), 31-53.

Seo, E. J.\& Park, J. W. (2018). A study on the effects of social media marketing activities on brand equity and customer response in the airline industry. Journal of Air Transport Management, 66, 36-41.

So, K. K., Wu, L., Xiong, L. \& King, C. (2017). Brand Management in the Era of Social Media: Social Visibility of Consumption and Customer Brand Identification. Journal of Travel Research, 1-16.

Stokes, R. (2011). E-Marketing: The essential guide to digital marketing $\left(4^{\text {th }}-5^{\text {th }}\right.$ Eds. $)$. United States of America: Quirk e-Marketing (Pty).

Tsimonis, G. \&Dimitriadis, S. (2014). Brand strategies in social media. Journal of Marketing Intelligence \& Planning, 32 (3), 328-344.

Turban, E., King, D., Lee, J. K., Liang, T. P., \&Turban, D.C. (2015). Electronic commerce: A Managerial and Social Networks Perspective. Cham: Springer.

Vukasovic, T. (2013).Building successful brand by using social networking media. Journal of Media and Communication Studies, 5 (6), 56-63. 
Wang, H. (2012). Six P's of youth social media from a young consumer's perspective. Young Consumers, 3 (13), 303-317.

Yadav, M. \&Rahman, Z. (2017).Measuring consumer perception of social media marketing activities in e-commerce industry. Journal of Scale development \& validation. 34 (7), 1294-1307.

Zeithaml, V., Berry, L. \& Parasuraman, A. (1996). The Behavioral Consequences of Service Quality. Journal of Marketing, 60, 31-46. 